UDC 631.445.4 (477.86)

\title{
CLAY PROFILE IN GREYZEMIC PHAEOZEMS OF THE PRE-CARPATHIAN REGION (UKRAINE)
}

\author{
Ihor Papish \\ Ivan Franko National University of Lviv, \\ P. Doroshenko St., 41, UA - 79007 Lviv, Ukraine, \\ e-mail: igorpapish@gmail.com
}

The aim of this article is to describe the formation of the chemic-mineralogical profile of Greyzemic Phaeozems on the various geomorphological surfaces in the Pre-Carpathian loess subprovince. The differentiation of the Greyzemic Phaeozems mineral mass is determined by the composition of soilforming rocks, the nature of the formation of different geomorphological surfaces and the peculiarities of the soil-forming process. The mineral profile of Greyzemic Phaeozems is differentiated into two parts, the upper one is within the humus horizon and the lower one is a weakly humus layer. At the high Pliocene terraces of the Prut River, its dual nature is caused by lithologic heterogeneity of the soil-forming rocks, and within the limits of the San-Dnister Upland, the active development of the processes of the leaching of clay material due to podzolization and soil profile gleyzation. The common regularity of the mineral profile of the Greyzemic Phaeozems this region is the uniformity of the ratio of the main mineral phases of the fine material, the active eluviation from the humus horizon of the smectite material, the relative accumulation in the humus horizon illite minerals, and various clastogenic non-clay minerals.

The negative trends in the clay profile evolution of Greyzemic Phaeozems cause the reduction of erosion resistance of these soils. The strength of the cohesion between soil aggregates is determined by the content of humus (humatic kind) and dominating smectite minerals in clay plasma. The processes of dehumification have been destabilized the mineral colloidal complex of Phaeozems and changed of smectite-illite dynamic equilibrium in soils. In Greyzemic Phaeozems the substantial loss of highly dispersive smectite material can be observed. The dominance of inactive bi-octahedral illite clay in the arable layer of Phaeozems reduces the role of clay plasma in the formation of water-stable micro- and macrostructure.

Key words: chemic-mineralogical profile of soil, podzolization, gleyzation, content of humus, chemical equilibrium in soils.

Humus is an organic component of the matrix substance of soils. The two interrelated trends can be outlined in the age dynamics of Phaeozems humus on the post-wild stage of soil evolution. Initially, the intensive mineralization of humus in the arable layer is followed by its intensive moving down the profile. The most mobile humus fractions, which are not connected with clay minerals migrate and indirectly affect their potential migration capacity. At the same time, the total reserves of humus in one meter layer of Phaeozems almost do not change. However, after 50 years of intensive land use the dehumification process has affected the whole soil profile and become irreversible. The same trend can be noticed on the fallow Phaeozems but on the smaller scale and without the mobile humus fractions, which were lost due to the mineralization on the post-wild stage. Obviously, the dynamic equilibrium disturbance between the organic and mineral components of Phaeozems matrix substance affects to some extend the

(C) Papish I., 2018 
stability of the latter. The highly active mineral part of the Phaeozems clay material vermiculite-smectite phase is the first to respond to such changes. These are the first substantial changes in the matrix organization of Phaeozems used on the slopes that will have profound environmental impacts. Evolution of Phaeozems, when caused by the changes in the silicate fraction of soils, is basically of irreversible degrading nature [9].

Greyzemic Phaeozems cover extensive natural Pre-Carpathian region within the limits of the valley-terrace complexes of the Dnister and Prut. They were formed in the thickness of gleyzed loessy loams with light and medium granulometric composition [7]. Soil samples were taken from the two representative profiles of Greyzemic Phaeozems (Podzolic Chernozems in Ukrainian Soil Systematic) from different natural regions of the Pre-Carpathian in Ukraine (fig. 1).

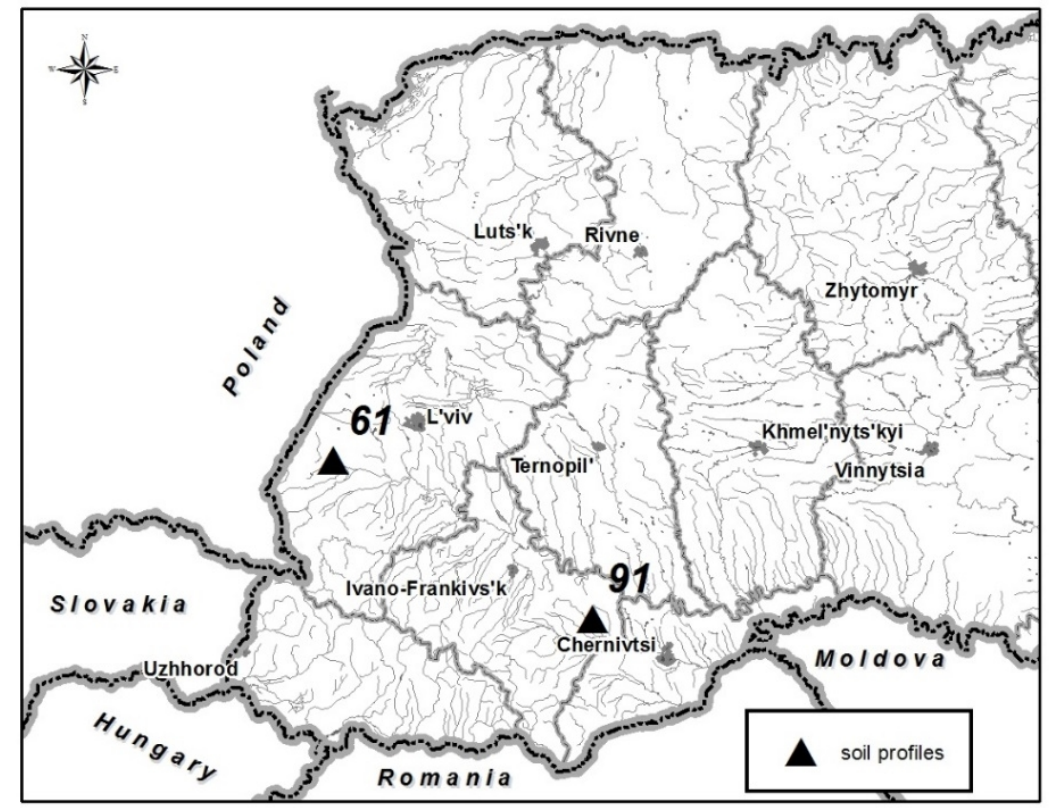

Fig. 1. Localization of soil profiles (Prut-Dnister Upland - pedon 91, San-Dnister Upland - pedon 61)

ис. 1. ісцезн ходження грунтових розрізів ( рут- ністерськ височин - розріз 91, янсько- ністерськ височин - розріз 61)

The granulometric analyses were conducted according to the standard methodology introduced by Kachynski (1965), using pyrophosphate method to prepare the soil [6]. Preparations of soil samples and allocating the clay fraction up to $1 \mu \mathrm{m}$ out of Phaeozems were made by Gorbunov's methodology [5].

The X-ray diffractometry analysis of the investigated soil samples was made in the laboratory of Institute of Geological Science of the Jagiellonian University, Krakow, Poland. Oriented preparation was obtained by methods of sedimentation the fractions on cover lenses. X-ray survey performed by diffractometer PHILIPS X'Pert APD (generator PW 1870 and PW 3020 vertical goniometer) and used CuKód-rays. Analysis carried out in the corners $2^{\circ}-52^{\circ} 2 \Theta$ with a speed of $0.02^{\circ} / 1 \mathrm{~s}$. Analysis were performed by increasing voltage $40 \mathrm{kV}$ and amperage of $30 \mathrm{~mA}$. Oriented preparations subjected to analysis in air-dry condition (Na-air) and after satiation it by vapour ethylene glycol (EG-sat). We have identified as individual pure minerals, 
as their packages in the mixed-planar minerals (fig. 2,3). The later minerals identified at grounds by Rule Meringa.

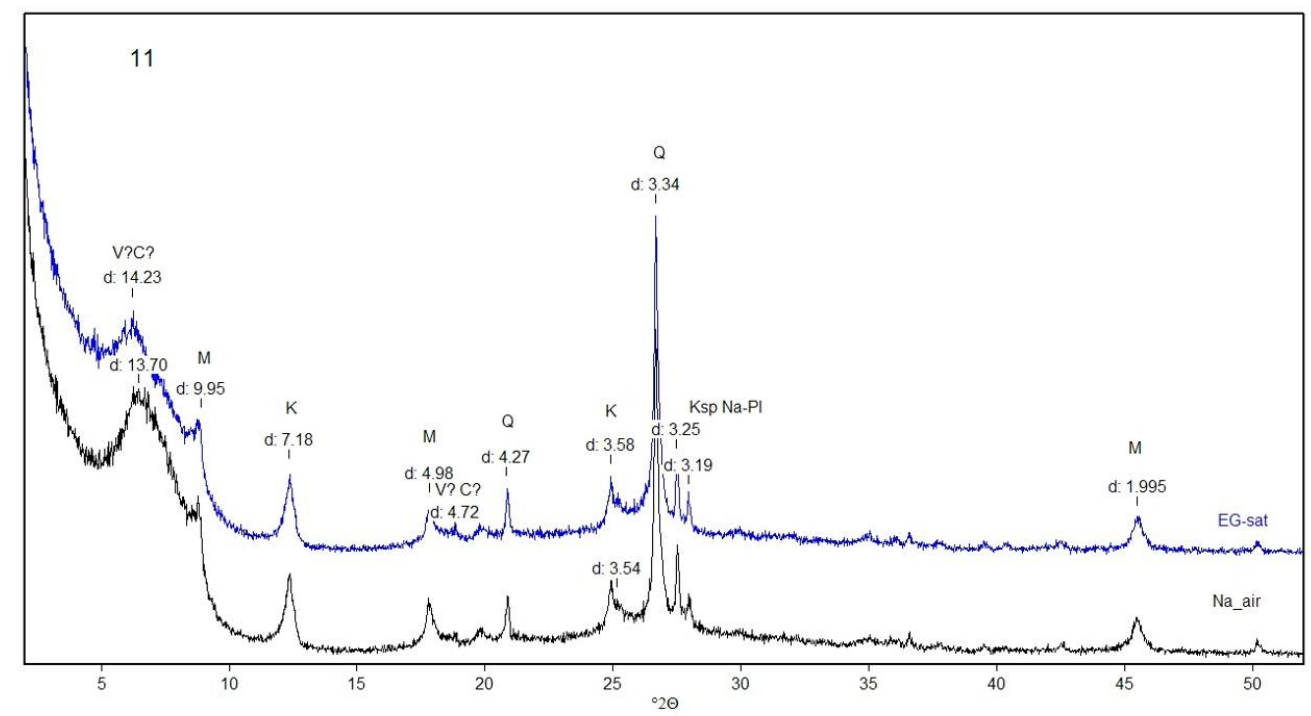

Sample 11, horizon A $(0-18 \mathrm{~cm})$ : mixed-planar minerals with dominate packets of Vermiculite $(\mathrm{V})$, Illite ( ), Kaolinite ( ), some quantity of Quarts (Q), K-Spars (Ksp) and Na-Plagioclase (Na-Pl). It may be Chlorite $(\mathrm{C})$ in this sample.

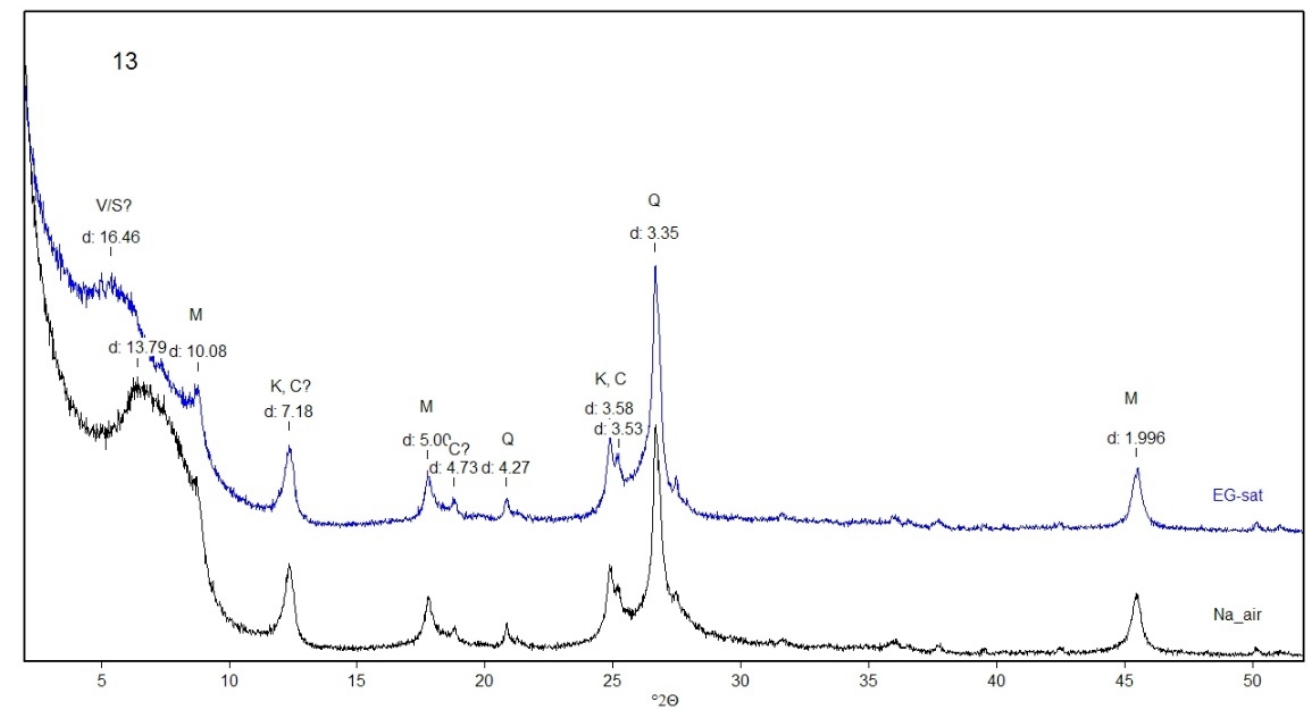

Sample 13, horizon AB $(60-70 \mathrm{~cm})$ : mixed-planar minerals with dominate packets of Vermiculite/Smectite (V/S), Chlorite (C), Illite ( ), Kaolinite ( ), some quantity of Quarts (Q) and $\mathrm{K}-\mathrm{Spars}(\mathrm{Ksp})$.

Fig. 2. X-ray diffractograms in clay fraction $(<1 \mu \mathrm{m})$ of Greyzemic Phaeozem (pedon 61) ис. 2. ентген-дифр ктогр ми глинистої фр кції (<1 мкм) чорноземів опідзолених (розріз 61) 


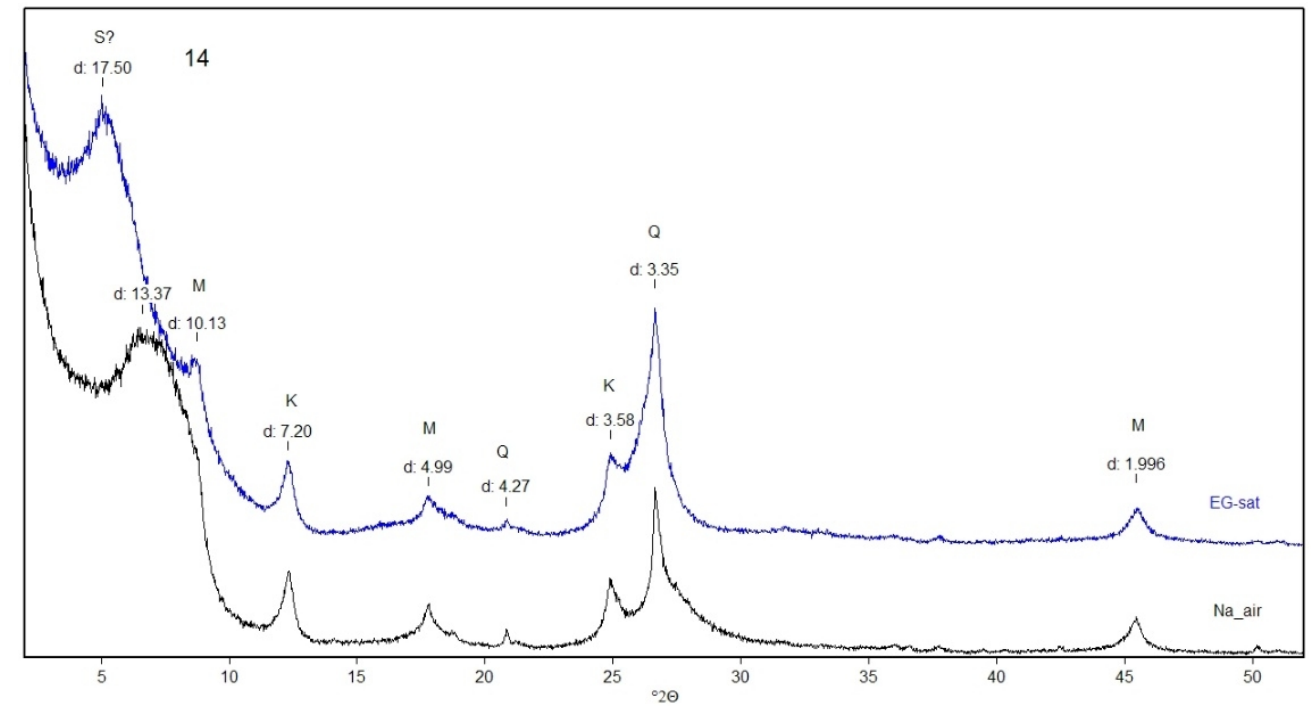

Sample 14, horizon ABC (100-110 cm): mixed-planar minerals with dominate packets of Smectite (S), Illite ( ), Kaolinite ( ), some quantity of Quarts (Q).

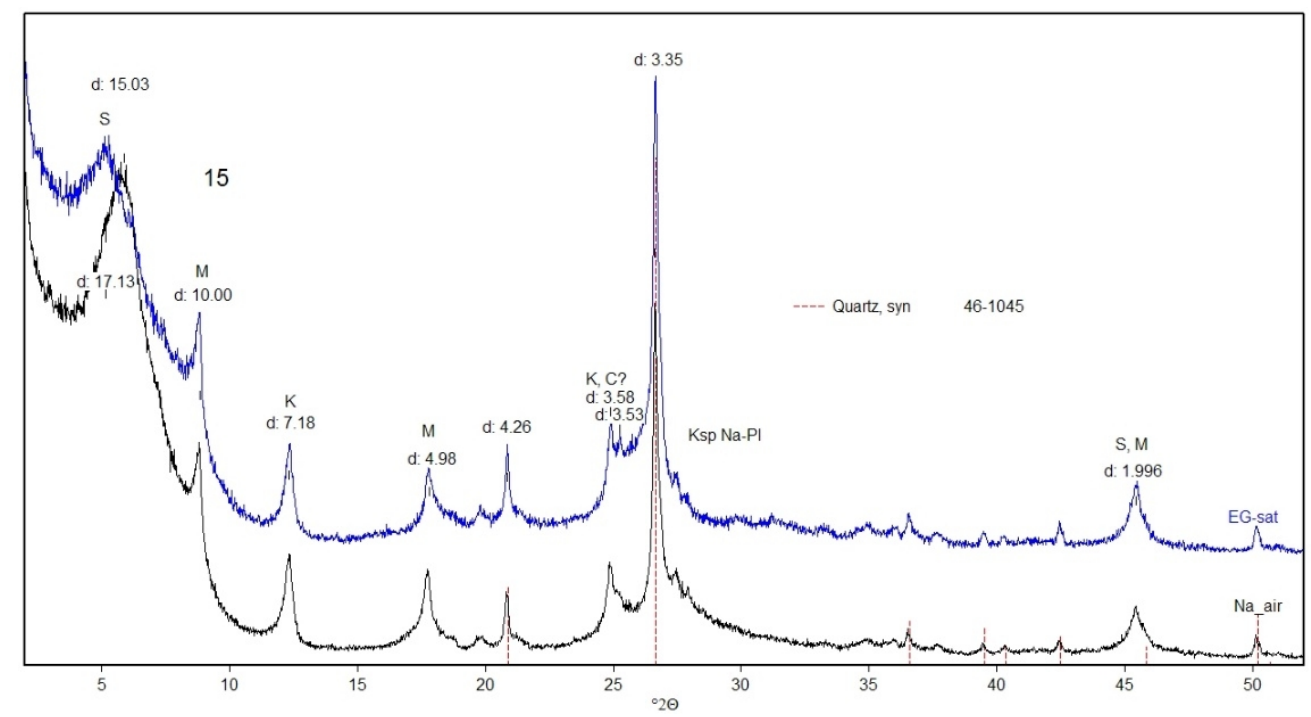

Sample 15, horizon C (190-200 cm): Smectite (S), Illite ( ), Kaolinite ( ), Quarts (Q), some quantity of K-Spars (Ksp) and Na-Plagioclase (Na-Pl). Reflect $3.52 \AA$ indicating there is a presence of Chlorite (C) here.

Fig. 2 (cont.). X-ray diffractograms in clay fraction $(<1 \mu \mathrm{m})$ of Greyzemic Phaeozem (pedon 61) ис. 2 (продовження). ентген-дифр ктогр ми глинистої фр кції (< 1 мкм)

чорноземів опідзолених (розріз 61) 


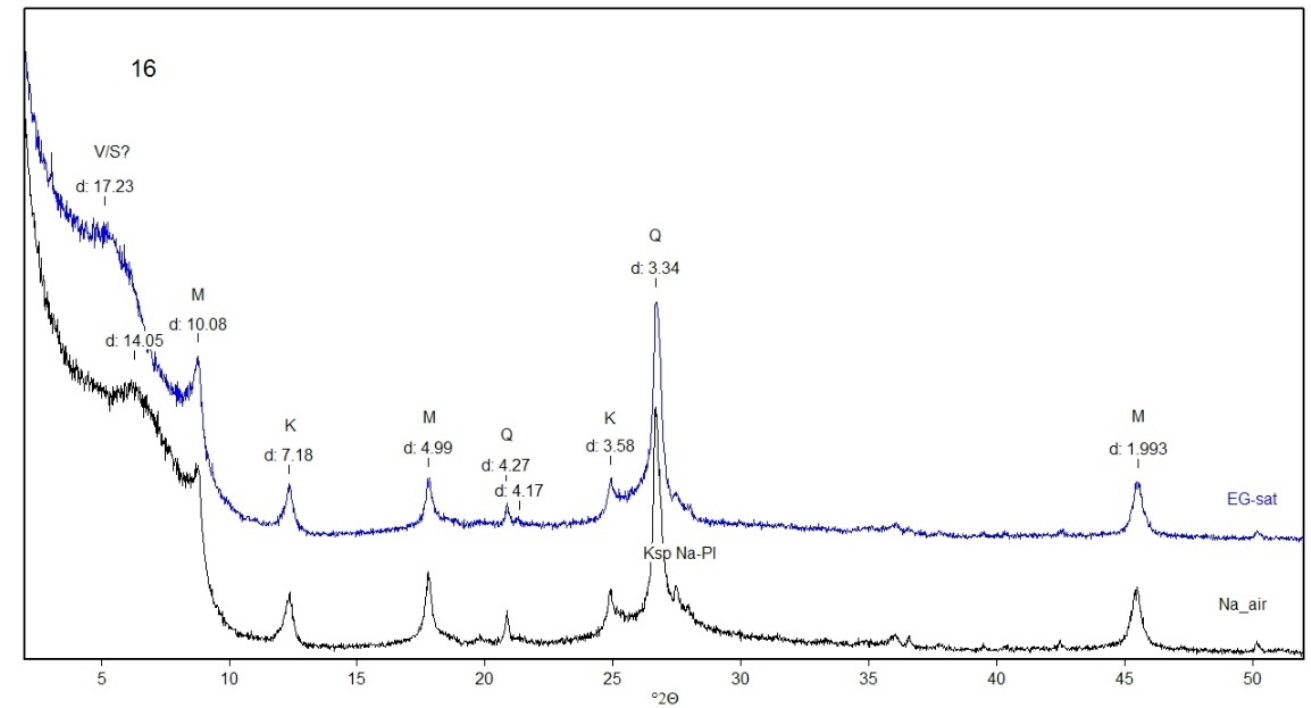

Sample 16, horizon A $(0-20 \mathrm{~cm})$ : mixed-planar minerals with dominate packets of Vermiculite/Smectite (V/S), Illite ( ), Kaolinite ( ), some quantity of Quarts (Q), K-Spars (Ksp) and Na-Plagioclase (Na-Pl).

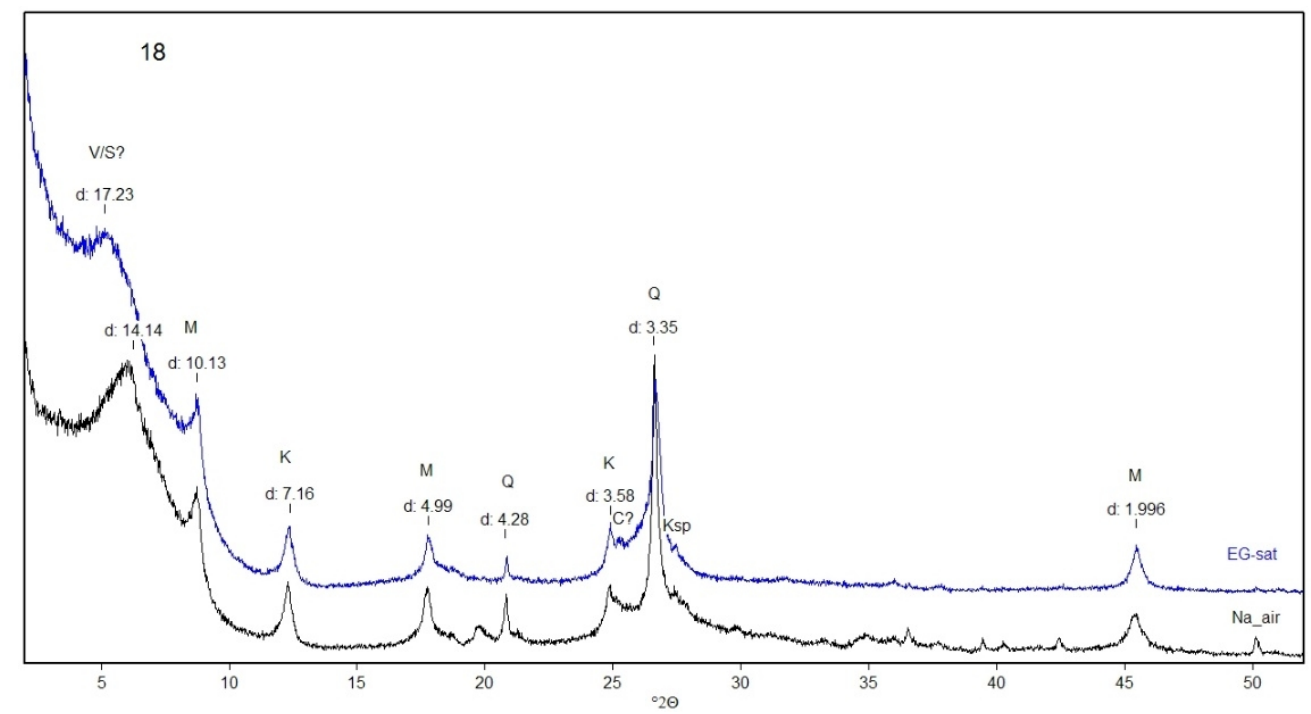

Sample 18, horizon AB $(60-70 \mathrm{~cm})$ : mixed-planar minerals with dominate packets of Vermiculite/Smectite (V/S), Illite ( ), Kaolinite ( ), some quantity of Quarts (Q) and K-Spars (Ksp). It may be Chlorite (C).

Fig. 3. X-ray diffractograms in clay fraction $(<1 \mu \mathrm{m})$ of Greyzemic Phaeozem of the Prut Pliocene terrace (pedon 91)

ис. 3. ентген-дифр ктогр ми глинистої фр кції (< 1 мкм) чорноземів опідзолених пліоценової тер си р. рут (розріз 91) 


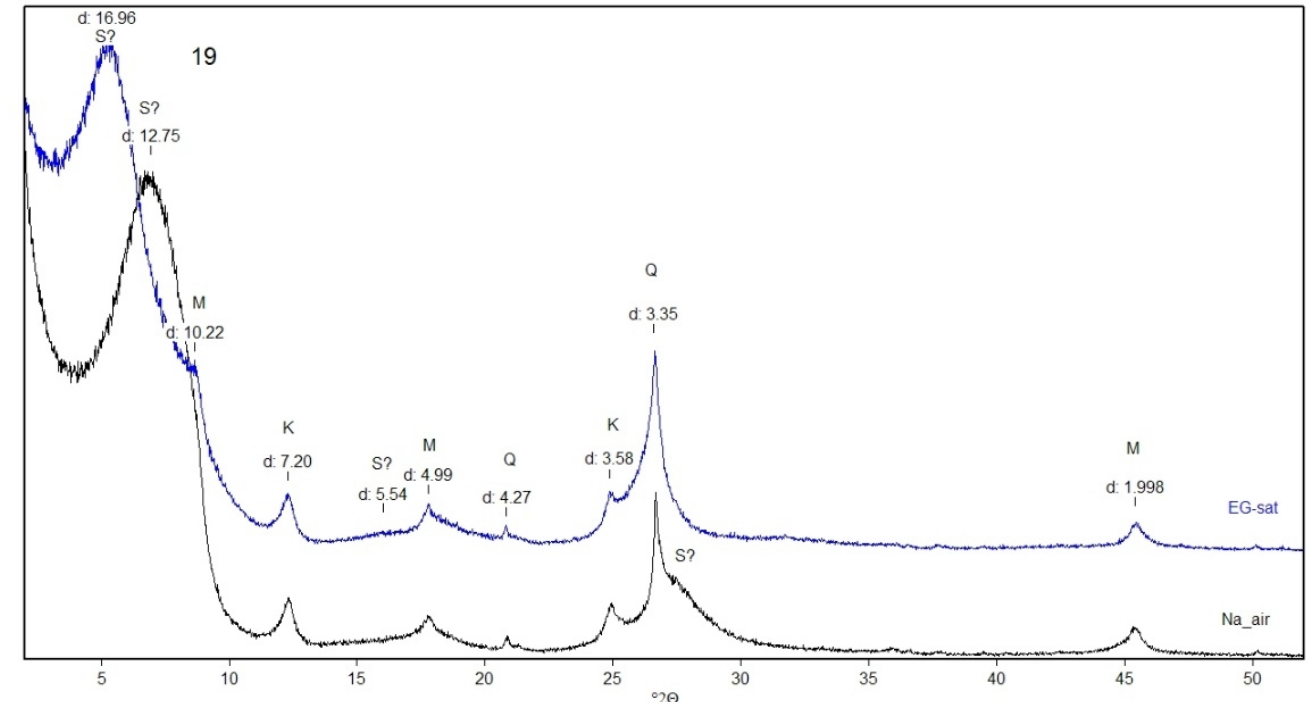

Sample 19, horizon ABC (100-110 cm): mixed-planar minerals with dominate packets of Smectite (S), Illite ( ), Kaolinite ( ) and some quantity of Quarts (Q).

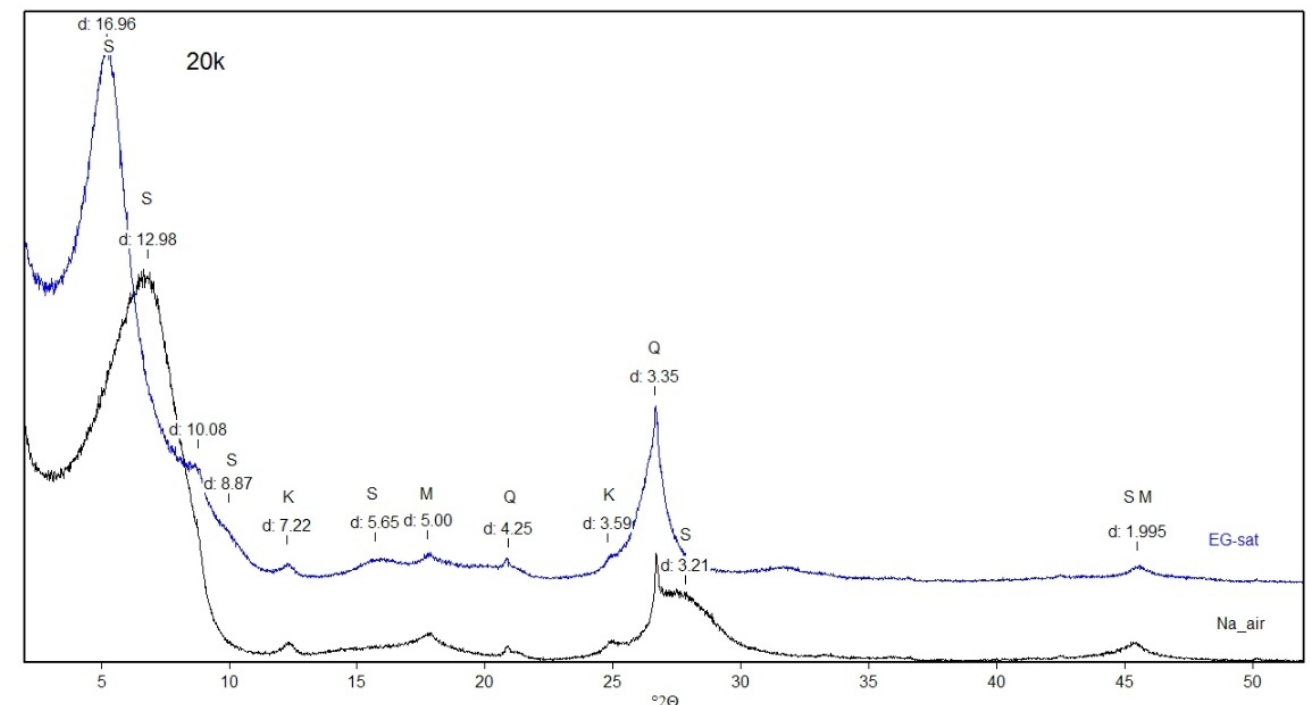

Sample 20k, horizon $\mathrm{C}_{(\mathrm{ca})}(170-180 \mathrm{~cm})$ : Smectite (S), Illite ( ), Kaolinite ( ) and some quantity of Quarts (Q).

Fig. 3 (cont.). X-ray diffractograms in clay fraction $(<1 \mu \mathrm{m})$ of Greyzemic Phaeozem of the Prut Pliocene terrace (pedon 91)

ис. 3 (продовження). ентген-дифр ктогр ми глинистої фр кції (< 1 мкм) чорноземів опідзолених пліоценової тер си р. рут (розріз 91) 
ISSN 2078-6441. Вісник Львівського університету. Серія географічна. 2018. Випуск 52

The negative balance of organic substance affects differently the stability of mineral plasma of Phaeozems. The stabilizing or destabilizing factor of Phaeozems erosion resistance is the nature of interrelation between its various components. In the wild steppe, this interrelation is optimal and balanced. One mass fraction of the highly dispersed humic organic substance accounts for approximately 2-3 mass fractions of the similarly active clay material. Having the distinctive zonal impact (the correlation between the humus content and physical clay), the character of this interrelation is the same for different Phaeozems subtypes. The imbalance becomes the impetus for evolutionary changes in the silicate part of Phaeozems. The main antierosion properties of soils depend on the composition and interrelation between the basic mineral phases of the clay minerals, particularly their structure forming ability and adhesion force between the aggregates.

The results of granulometric analysis of Greyzemic Phaeozems of Pre-Carpathian region show the correlative dependence between the humus content and physical clay (the matrix component of soil) on one hand, and the behaviour of fine-grained clay fraction on the other hand (table 1).

Table 1

Content of humus and carbonates, granulometric composition in Greyzemic Phaeozems міст гумусу і к рбон тів, гр нулометричний скл д чорноземів опідзолених

\begin{tabular}{|c|c|c|c|c|c|c|c|c|c|}
\hline \multirow[b]{2}{*}{$\begin{array}{l}\text { Depth } \\
\text { (cm) }\end{array}$} & \multirow[b]{2}{*}{$\begin{array}{c}\text { Humus } \\
(\%)\end{array}$} & \multirow[b]{2}{*}{$\begin{array}{c}\mathrm{CaCO}_{3} \\
(\%)\end{array}$} & \multicolumn{7}{|c|}{ Size of soil particles (mm), amount (\%) } \\
\hline & & & 1-0.25 & $\begin{array}{c}0.25- \\
0.05\end{array}$ & $\begin{array}{c}0.05- \\
0.01\end{array}$ & $\begin{array}{l}\text { 0.01- } \\
\text { 0.005 }\end{array}$ & $\begin{array}{c}0.005- \\
0.001\end{array}$ & $<0.001$ & $<0.01$ \\
\hline \multicolumn{10}{|c|}{ Greyzemic Phaeozems on the loess loams of the San-Dnister Upland (pedon 61) } \\
\hline $0-18$ & 4.2 & 0.0 & 0.0 & 10.0 & 60.8 & 14.4 & 9.6 & 5.2 & 29.2 \\
\hline $30-40$ & 3.4 & 0.0 & 0.0 & 10.0 & 60.8 & 12.8 & 9.2 & 7.2 & 29.2 \\
\hline $60-70$ & 1.6 & 0.0 & 0.0 & 12.8 & 60.4 & 7.6 & 10.4 & 8.8 & 26.8 \\
\hline $100-110$ & 0.3 & 0.0 & 0.0 & 12.0 & 60.0 & 4.8 & 5.2 & 18.0 & 28.0 \\
\hline 190-200 & 0.3 & 0.0 & 0.0 & 7.2 & 60.8 & 10.4 & 5.6 & 16.0 & 32.0 \\
\hline \multicolumn{10}{|c|}{$\begin{array}{c}\text { Greyzemic Phaeozems on the loess loams which is underlied from the depth } 180 \mathrm{~cm} \text { by thin-sand } \\
\text { alluvium of Prut Pliocene terrace at the Prut-Dnister Upland (pedon 91) }\end{array}$} \\
\hline $0-20$ & 3.3 & 0.0 & 1.2 & 12.4 & 44.4 & 11.2 & 8.8 & 22.0 & 42.0 \\
\hline $30-40$ & 2.7 & 0.0 & 1.2 & 12.0 & 43.2 & 8.4 & 12.4 & 22.8 & 43.6 \\
\hline $60-70$ & 1.5 & 0.0 & 1.5 & 20.5 & 31.6 & 10.0 & 12.0 & 24.4 & 46.4 \\
\hline $100-110$ & 0.7 & 0.0 & 2.3 & 24.1 & 30.0 & 6.8 & 8.0 & 28.8 & 43.6 \\
\hline $170-180$ & 0.5 & 2.0 & 8.0 & 36.4 & 21.6 & 4.4 & 8.4 & 21.2 & 34.0 \\
\hline $190-200$ & - & 0.0 & 22.5 & 59.9 & 7.2 & 2.0 & 1.2 & 7.2 & 10.4 \\
\hline
\end{tabular}

The consequence of long evolution of wet forest-steppe Phaeozems is the formation of their typical clay profile [3]. Greyzemic Phaeozems have a distinctive eluvial-illuvial type of vertical distribution of the clay fraction. By this parameter, they belong to the genus of texturedifferentiated Phaeozems. On the background of one-ordinal parameters of the humus content (3.3-4.2\%), Greyzemic Phaeozems of San-Dnister Upland have less content of physical clay (the size of particles is less than $0.01 \mathrm{~mm}$ ) than their analogues of Prut-Dnister Upland with three or four times less clay in their composition. From the two similar genetic soil types, greater erosion resistance has the soil, which is heavier by its granulometric composition and contains more silt capable of aggregation. The high content of a loessial dust fraction 
$(0.05-0.01 \mathrm{~mm})$ which greatly reduces water resistance of the structure is particularly unfavourable. In Greyzemic Phaeozems of San-Dnister Upland, the content of this fraction is higher by $15-20 \%$ than in other soils.

The mineralogical composition of the clay fraction $(<1 \mu \mathrm{m})$ of Greyzemic Phaeozems in Pre-Carpathian region of Ukraine is not homogeneous within the profile (table 2).

Table 2

Correlation of the basic mineral phases in fraction $<1 \mu \mathrm{m}$, took out of Greyzemic Phaeozems and quantitative estimation of clay plasma

піввідношення основних мінер льних ф з фр кції < 1 мкм, виділеної з чорноземів опідзолених і кількісн оцінк глинистої пл зми

\begin{tabular}{|c|c|c|c|c|c|c|c|c|c|}
\hline \multirow{2}{*}{$\begin{array}{l}\text { Depth } \\
(\mathbf{c m})\end{array}$} & \multirow{2}{*}{$\begin{array}{c}\text { Fraction } \\
<1 \mu \mathrm{m}(\%)\end{array}$} & \multicolumn{3}{|c|}{$\begin{array}{l}\text { Stratified silicates } \\
\text { distribution }(\%)\end{array}$} & \multicolumn{3}{|c|}{$\begin{array}{c}\text { Framework silicates } \\
\text { distribution }\end{array}$} & \multirow[t]{2}{*}{ II $\mathbf{S}$} & \multirow[t]{2}{*}{ IS S } \\
\hline & & $\mathbf{M S}^{\mathbf{1}}$ & M & $\mathbf{K}+\mathbf{C h}$ & $\mathbf{Q}$ & $-\mathrm{Sp}$ & Pl & & \\
\hline \multicolumn{10}{|c|}{ Greyzemic Gleyic Phaeozems on the loess loams in the San-Dnister Upland (pedon 61) } \\
\hline $0-18$ & 5.2 & 43 & 46 & 11 & +++ & ++ & + & 10.7 & 2.3 \\
\hline $30-40$ & 7.2 & 36 & 51 & 13 & ++ & + & $*$ & 14.2 & 5.8 \\
\hline $60-70$ & 8.8 & 40 & 48 & 12 & $*$ & $*$ & $*$ & 12.0 & 3.6 \\
\hline $120-130$ & 18.0 & 54 & 39 & 7 & $*$ & $*$ & $*$ & 7.2 & - \\
\hline 190-200 & 16.0 & 51 & 43 & 7 & ++ & + & + & 8.4 & - \\
\hline \multicolumn{10}{|c|}{$\begin{array}{c}\text { Greyzemic Phaeozems on the loess loams, which is underlied from the depth } 180 \mathrm{~cm} \text { by thin-sand } \\
\text { alluvium of Prut Pliocene terrace at the Prut-Dnister Upland (pedon 91) }\end{array}$} \\
\hline $0-20$ & 22.0 & 48 & 49 & 3 & ++ & + & + & 10.2 & 5.7 \\
\hline $30-40$ & 22.8 & 44 & 50 & 6 & + & $*$ & $*$ & 11.4 & 6.9 \\
\hline $60-70$ & 24.4 & 46 & 47 & 8 & + & $*$ & $*$ & 10.2 & 5.7 \\
\hline $100-110$ & 20.8 & 66 & 30 & 4 & + & $*$ & $*$ & 4.5 & - \\
\hline $170-180$ & 21.2 & 76 & 22 & 2 & $*$ & $*$ & $*$ & - & - \\
\hline 190-200 & 7.2 & 68 & 30 & 2 & $*$ & $*$ & $*$ & - & - \\
\hline
\end{tabular}

${ }^{1}$ MS: Illite-Smectite; M: Illite; K+Ch: Kaolinite+Chlorite; Q: Quartz; K-Sp: -field Spars; Pl: Plagioclase; framework silicates: ${ }^{+}$very low,${ }^{++}$poor, ${ }^{+++}$marked, ${ }^{*}$ not discovered; IIIS - index of intensity of weathering, illite-smectite; ISIS - index of weathering stress, illite-smectite.

The upper part of the profile is clearly distinctive because it is high in clastogenic minerals such as Quartz, Plagioclase, Microcline and Hornblende. The banding silicates are present within the profile in the form of disordered mixed-planar illite-smectite formations with the high content (over 50\%) of smectite packets (33-63\%), Illite (33-52\%), Kaolinite and Chlorite (4-15\%).

The illite-smectite and illite phases of studied Phaeozems have the contrary character of profile distribution. The clay profile of Greyzemic Phaeozems is characterized by eluvial type of smectite phase distribution. Illite and Kaolinite are accumulated in the humus horizon and have progressive-accumulative type of profile. This type distribution of clay minerals is inherent not only to Ukrainian Wet forest-steppe Phaeozems but also to Moldova wet steppe Chernozems and Phaeozems [4]. Thus, Phaeozems type of soil formation in forest-steppe zone with periodical leaching type of soil water regime is prone to redistribution of the smectite phase of clay material, which is less resistant to weathering and mobile. 
Highly dispersive banding silicates are more resistant to destruction than organic matter and carbonates. For this reason, they record and store the changes in Phaeozems more reliably. At the same time, as the unstable minerals of magmatic origin they are not able to reproduce under conditions of soil formation (normal temperature and pressure) [2]. Their content in the soil compared to the more stable minerals can only reduce. Among the two main mineral phases of Phaeozems clay plasma (Smectite and Illite) which predominate in the composition of Phaeozems, bi-octahedral Illite with the curve of izoclay profile distribution is the most resistant to weathering. It largely dominates in the composition of Illit minerals of Phaeozems humus horizon owing to the destruction of tri-octahedral Illites. This highly dispersive mineral can be accumulated due to the destruction and movement of less stable and more mobile Smectites and tri-octahedral Illites [3]. Probability of the processes of non-exchange sorption of Potassium by highly charged Smectite ("illitizating process") in rainfed drylands and the deficit of Potassium supply is very low [3, 8].

The intensity of transformation changes in the fractions of Phaeozems mineral profile (less than $1 \mu \mathrm{m}$ ) can be assessed by the index of intensity of weathering, illite/smectite (IIIS) in terms of the changes in illite/smectite correlation [4]. This index is the ratio of the content of stable bi-octahedral Illite (in percentage) to the content of unstable Smectite in the fraction multiplied by 10 to get an integer number. The stress of mineral transformations in a series of changes of illite/smectite correlation throughout the profile can be evaluated by the index of weathering stress, illite/smectite (ISIS) which equals to the difference between IIIS of the top horizon and a rock [4].

The high indexes of intensity and stress of mineral transformations enable us to diagnose the mineralogical condition of clay material of the studied Phaeozems. Greyzemic Phaeozems of San-Dnister Upland are characterized by greater intensity and depth of transformation processes in the silicate part of the profile compared to Phaeozems of Prut-Dnister Upland in which these processes take place mainly in the arable layer. As Pre-Carpathian Greyzemic Phaeozems are concerned, the intensity of transformation processes is increasing with strengthening of soil hydromorphism. The rise in the ISIS of these Phaeozems indicates the increasing loss of Smectite. All in all, this shows that the clay of Greyzemic Phaeozems amalgamates and reduces its activity due to the accumulation of rigid illite structures and other clastogenic minerals.

Conclusions

1. The dominance of inactive illite clay in the whole humus horizon $(0-70 \mathrm{~cm})$ of all Greyzemic Phaeozems as well as the high content of Kaolinite reduce the role of clay plasma as the major stabilizer of organic matter and soil microstructure along with the accelerated humus mineralization.

2. Bi-octahedral Illite and Kaolinite unlike Smectite reduce erosion resistance of arable Greyzemic Phaeozems layer since they ensure poor adhesion of soil particles. Such changes lead to comminution of the soil macro- and microstructure, reduction of its hardness and water resistance, boost of lumpiness of the arable and under-plough layers of Phaeozems.

3. Being the object of intensive use in grain-tilled crop rotations on the slopes, Phaeozems with degraded clay plasma in the arable horizon are the favourable substrate for the development of erosion processes. Due to the irrational land use, the modern tendencies in the evolution of highly dispersive silicate part of Phaeozems indicate the degradation of their clay profile and loss of very important ecological functions. 
1. Chizhikova N. P., Gradusov B. P. Minerallogical composition of the fine-dispersed fractions of loess and soil processes developed in them // Geojournal. 1995. V. 36, N 2-3. P. 179-189.

2. Egli M., Mirabella A., Sartori $G$. The role of climate and vegetation in weathering and clay mineral formation in late Quaternary soils of the Swiss and Italian Alps // Geomorphology. 2008. Vol. 102. P. 307-324.

3. лексеев . . инер логический сост в и эволюция глинистой ч сти черноземов олд вии // очвоведение. 1977. № 2. . 12-18.

4. лексеев . . пособ оценки минер логического состояния силик тной ч сти черноземов // очвоведение. 2012. № 2. . 189-199.

5. орбунов . . етоды подготовки почв, грунтов, ос дков рек и морей к минер логическому н лизу // очвоведение. 1960. № 11. . 79-81.

6. чинский . . изик почв. ., 1965. 323 с.

7. піш . ., озняк . . роблеми генези чорноземів личини // існик ьвів. ун-ту. 2010. ер. геогр. ип. 38. . 271-280.

8. озняк . . рош емые черноземы юго-з п д кр ины. . : , 1997.240 с.

9. околов . ., ронов . ., олпешт . . линистые минер лы в почв х. ул : 2005. $336 \mathrm{c}$.

\section{REFERENCES}

1. Chizhikova, N. P., \& Gradusov, B. P. (1995). Mineralogical composition of the finedispersed fractions of loess and soil processes developed in them. Geojournal, 36(2-3), 179-189.

2. Egli, M., Mirabella, A., \& Sartori, G. (2008). The role of climate and vegetation in weathering and clay mineral formation in late Quaternary soils of the Swiss and Italian Alps. Geomorphology, 102, 307-324.

3. Alekseev, V. E. (1977). Mineralogicheskij sostav i evolutsia glinistoj chasti chernozemov Moldavii. Pochvovedeniye, 2, 12-18 (in Russian).

4. Alekseev, V. E. (2012). Sposob otsenki mineralogicheskogo sostoyaniya silikatnoj chasti chernozemov. Pochvovedeniye, 2, 189-199 (in Russian).

5. Gorbunov, M. I. (1960). Metodika podgotovki pochv, gruntov, vzvesej rek i osadkov morej k mineralogicheskomu analizu. Pochvovedeniye, 11, 79-81 (in Russian).

6. Kachynskiy, N. A. (1965). Phizika pochv. Moscow, 323 p. (in Russian).

7. Papish, I. Ya., \& Pozniak, S. P. (2010). Genesis problems of chernozems of the Galicia. Visnyk of the Lviv University. Series Geography, 38, 271-280 (in Ukrainian).

8. Pozniak, S. P. (1995). Oroshaemye chernozemy Jugo-Zapada Ukrainy. Lvov, 240 p. (in Russian).

9. Sokolova, T. A., Dronova, T. Ya., \& Tolpeshta, I. I. (2005). Glinistyje mineraly v pochvah. Tula, 336 p. (in Russian). 


\author{
$(\quad)$ \\ гор піiII \\ ввівський н ціон льний університет імені в н \\ вул. . орошенк, 41, 79007, м. ьвів, кр їн, \\ e-mail: igorpapish@gmail.com
}

ідобр жено особливості формув ння хіміко-мінер логічного профілю чорноземів опідзолених н різних геоморфологічних поверхнях ередк рп тської лесової підпровінції. иференці ція мінер льної м си чорноземів опідзолених визн чен скл дом грунтотворних порід, х р ктером формув ння різних геоморфологічних поверхонь і особливостями грунтотворного процесу.

інер льний профіль чорноземів опідзолених диференційов ний н дві ч стини: верхню - у меж х гумусового горизонту, і нижню - сл бкогумусов ну товщу. високих пліоценових тер с $\mathrm{x}$ p. рут його ду лістичн природ виклик н літологічною неоднорідністю грунтотворних порід, у меж $\mathrm{x}$ янсько- ністерської височини - ктивним розвитком процесів елювіюв ння глинистого м тері лу вн слідок опідзолення і профільного оглеєння грунтів. пільною 3 кономірністю мінер льного профілю чорноземів опідзолених цього регіону є однотипність співвідношення основних мінер льних ф з тонкодисперсного м тері лу, ктивне елювіюв ння з гумусового горизонту смектитового м тері лу, відносн кумуляція в гумусовому горизонті іліту т різних кл стогенних неглинистих мінер лів.

ег тиві тенденції в еволюції глинистого профілю чорноземів опідзолених призводять до зміни їхньої протиерозійної стійкості. ил зчеплення між грунтовими грег т ми визн ч ється високим вмістом гум тного гумусу і домінув нням у скл ді глинистої пл зми грунтів мінер лів монтморилонітової групи. роцеси дегуміфік ції дест білізув ли мінер льний колоїдний комплекс чорноземів і змінили смектит-ілітову дин мічну рівнов гу в грунт х. ст новлено, що чорноземи опідзолені втр тили високодисперсний смектитовий м тері л. омінув ння в глинистому м тері лі орного горизонту чорноземів опідзолених не ктивного диокт едричного іліту зменшує роль глинистої пл зми у формув нні водостійкої мікро- і м кроструктури.

лючові слов : хіміко-мінер логічний профіль грунту, опідзолення, оглеєння, вміст гумусу, хімічн рівнов г в грунт $\mathrm{x}$. 